\title{
Species assemblages of leptocephali in the Sargasso Sea and Florida Current
}

\author{
M. J. Miller* \\ Department of Zoology, 5751 Murray Hall, University of Maine, Orono, Maine 04469-5751, USA
}

\begin{abstract}
Regional assemblages of leptocephali of 5 families of shelf eels (Chlopsidae, Congridae, Moringuidae, Muraenidae and Ophichthidae) from the Sargasso Sea and Florida Current were compared with hydrographic features and adult distributions. There were 2 major patterns in the distributions of the $>37$ species of leptocephali that were collected. First, more species and greater abundances were found at or south of fronts in the Subtropical Convergence Zone (STCZ) of the Sargasso Sea, with the most diverse assemblages at stations closest to fronts in the west. Second, the smallest leptocephali of all species were located close to the Bahama Banks, in the Florida Current and in stations close to southerly fronts in the western STCZ. The most distinct discontinuities in numbers of species occurred at fronts at the boundary between southern Sargasso Sea surface water and mixed convergence zone water Impoverished assemblages were found north of these fronts and in the eastern STCZ. Species richness was highest in the Florida Current and at the westernmost frontal station in the STCZ. Anticyclonic circulation northeast of the northern Bahamas may facilitate entrainment of leptocephali from the Bahamas and Florida Current into fronts in the STCZ, which appear to transport leptocephali eastward. The circulation patterns of the region are hypothesized to influence both the regional assemblage structure and the diversity of life history strategies that may be used by eels inhabiting the region.
\end{abstract}

KEY WORDS: Leptocephali Angulliformes Distribution - Species assemblages - Sargasso Sea Florida Current Fronts Bahamas - Life history Spawning L Larval transport

\section{INTRODUCTION}

Leptocephali differ from other larval fishes in having a variety of unique morphological characteristics, a long larval duration and an unusually large size increase before metamorphosis (Hulet \& Robins 1989 Smith 1989a). Although the leptocephalus is a larval type shared by the elopiform, saccopharyngiform and notacanthiform fishes, the largest group of fishes with this type of larva are the eels of the order Anguilliformes. The adult life histories of eels include those of catadromous Anguilla species, completely pelagic 'oceanic' species, continental slope and deep benthic species, and marine 'shelf' species, the latter living in continental shelf habitats and around islands (Castle

\footnotetext{
- Present address: School of Biological Sciences, Victoria University of Wellington, PO Box 600, Wellington, New Zealand
}

1984). The juveniles and adults of some species appear to be relatively abundant and potentially ecologically important components of some of the diverse habitats in which they are found, but like leptocephali, are rarely seen and difficult to capture without specialized gear. Leptocephali are pelagic and inhabit the upper few hundred meters of the water column throughout the world's oceans, primarily in tropical and subtropical areas. Because most appear to avoid standard plankton nets under any conditions and larger trawls during the day, the abundances and potential ecological significance of leptocephali have probably been underestimated. Despite the ubiquitous presence of leptocephali in the surface layer, very little is known about their ecology. The leptocephalus stage may last from several months to more than a year, providing the potential for drift with ocean currents for long distances from where they were spawned. The best known examples of long distance transport are the 
movements of the leptocephali of the catadromous American and European eels (Anguilla spp.) from the southern Sargasso Sea of the western North Atlantic (WNA) to the coasts of North America and Europe.

The spawning locations in the Sargasso Sea and the general distributions of the leptocephali of the American and European eels are relatively well known (Schmidt 1922, Schoth \& Tesch 1982, Kleckner et al. 1983, Boëtius \& Harding 1985, Kleckner \& McCleave 1985, 1988, Tesch \& Wegner 1990) in comparison to the other 12 families of anguilliform eels whose leptocephali are commonly found in the WNA. Some information is available on the distributions and diets of adult eels in the WNA (Böhlke \& Chaplin 1968, Böhlke 1989), but little is known about the reproductive ecology of most marine eels, other than a few observations of apparent spawning migrations (Cohen \& Dean 1970), reproductive behavior (Moyer \& Zaiser 1982, Ferraris 1985), the presence of eggs and leptocephali (Castle \& Robertson 1974) and gonadal morphology (Böhlke 1989, Fishelson 1992) in a few shelf species.

This study deals with the leptocephali of shelf eels of the Chlopsidae, Congridae, Moringuidae, Muraenidae and Ophichthidae. These taxa are distributed throughout the world in tropical and subtropical regions, but no study has described how leptocephali of these families are distributed relative to hydrographic conditions or to adult distributions. When and where these species spawn in the WNA and the drift patterns of their leptocephali are not known, other than general indications that Conger oceanicus (Schmidt 1931, McCleave \& Miller 1994) and Moringua edwardsi (Castle 1979) spawn in the vicinity of the West Indies. These studies were possible largely as a result of collections made during cruises designed to investigate the spawning ecology of Anguilla spp., which also contained leptocephali of many other eel families.

Leptocephali from 13 eel families collected during a series of 4 cruises in the Subtropical Convergence Zone (STCZ) were used in a study of species assemblages in relation to density structure in the region (Miller \& McCleave 1994). This broad study used catch rates of leptocephali collected at individual stations in 7 across-front transects to analyze species assemblage structure, general length class structure and alongtransect catch rates of leptocephali of oceanic, shelf and Anguilla species. Assemblages of leptocephali in the STCZ were similar during February, March and April of 3 different years. Oceanic species and the most abundant shelf species, Ariosoma balearicum, had high catch rates at some stations on both sides of fronts, but catch rates of other shelf species were greatest in the western transects and in stations at, or south of, fronts.

The present paper uses species abundance data to compare regional assemblages of the leptocephali of 5 families of shelf eels (Chlopsidae, Congridae, Moringuidae, Muraenidae and Ophichthidae) in the frontal transects (see Miller \& McCleave 1994) with assemblages from 3 other cruises with stations in the STCZ, close to the Bahamas or in the Florida Current. These 7 cruises were made by 3 different institutions during the February-to-April season between 1979 and 1989 and were designed to examine the distributional ecology of leptocephali of 2 species of Anguilla or the zoogeography of mesopelagic fishes. This paper characterizes and identifies major differences in species composition among assemblages of leptocephali of shelf eels in different regions. Species richness is assessed in relation to density structure in the STCZ, and the geographic distributions of the smaller size classes of leptocephali are described. These distributions and the relationships among assemblages in different areas are discussed in relation to locations of frontal features, current systems, shelf areas and the life histories of eels in the region.

\section{MATERIALS AND METHODS}

Study area. The Sargasso Sea is part of the western half of a large anticyclonic gyre, which has the Florida Current and Gulf Stream flowing to the north and northeast along the Atlantic coast of North America. The southern half of this flow, from the Straits of Florida to Cape Hatteras is narrow with minor meanders and is called the Florida Current. It transports water from the Caribbean and Gulf of Mexico through the Straits of Florida, combines with water from the Sargasso Sea as it flows north of the Bahamas (Fig. 1), and forms the Gulf Stream off Cape Hatteras. The Florida Current and Gulf Stream form the western and northern boundary of the Sargasso Sea, but the southernmost part of the Florida Current is separated from the southwest Sargasso Sea by the banks of the northern Bahamas (Fig. 1b). These banks are inhabited by many eel species of the 5 major shelf families (Böhlke \& Chaplin 1968, Böhlke 1989) and form the largest area of shelf habitat adjacent to the Sargasso Sea. The 2 largest banks of the Bahamas are separated by the Providence Channel. This channel connects the Sargasso Sea and Florida Current, and in the east it opens into the Tongue of the Ocean, which extends deep into the southern bank (Fig. 2). The smaller banks of the Bahamas and the Antilles form the southern boundary of the Sargasso Sea.

The southern part of the Sargasso Sea, between $22^{\circ}$ and $32^{\circ} \mathrm{N}$, is the location of the STCZ (Fig. 1), which has a dynamic pattern of fronts that are especially prominent features during winter and spring. These fronts form in the upper $200 \mathrm{~m}$, where colder 
Fig. 1. Transect and station positions showing (a) frontal transects (-) and all individual stations of Cruises C181 ( $\mathbf{\wedge}$ ), AD79 (o) and 831 (a), and (b) assemblage stations with patterns of pooling and labelling (for the cluster analysis and ordination) within transects or cruises and general locations of fronts indicated. Transect stations were separated into 2 locations $\bullet$ and $0-$ ) labelled according to the transect abbreviations in (a): $N$, north; $S$, south; $E$, east $W$, west; FR, front. Note that $832 \mathrm{E}$ was pooled into 1 location. The assemblage stations of CI81 $(\Delta, \Delta)$ and $\operatorname{AD79}(\mathbf{0}, \bullet)$ are also separated into 2 locations. Sigma-t 25.0 and 25.6 isopycnals (indicating frontal positions) are drawn consistent with surface expression along transects (except 832E) and general locations east of $67^{\circ} \mathrm{W}$ during Cruise AD79
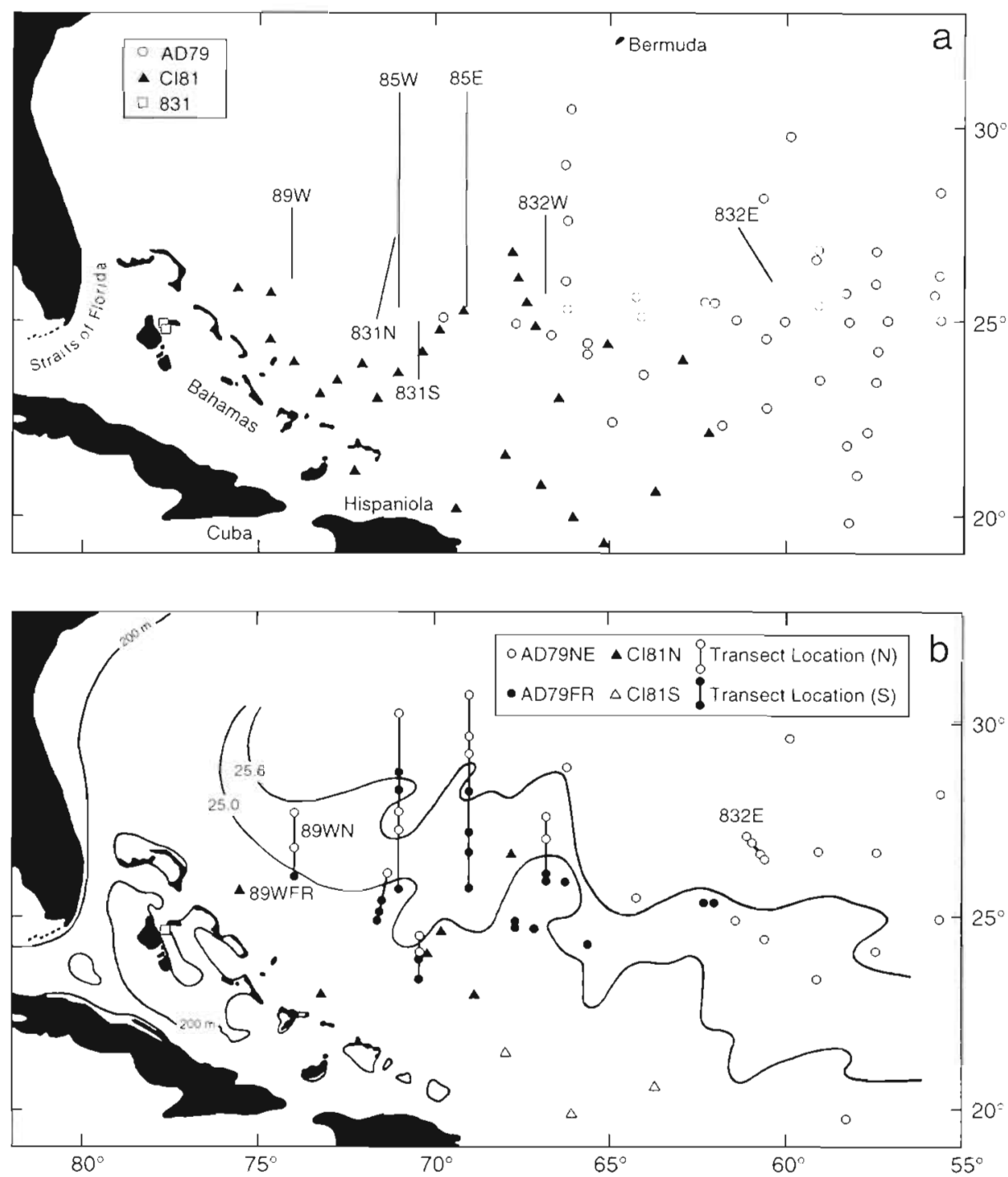

water of the northern Sargasso Sea meets the warmer mixed layer of lower density water in the upper $100 \mathrm{~m}$ of the southern Sargasso Sea (Wegner 1982, Kleckner \& McCleave 1988, Halliwell \& Cornillon 1989, Eriksen et al. 1991, Halliwell et al. 1991, Pollard \& Regier 1992). Strong frontal jets occur in association with the surface expression of well developed fronts and when surface water converges toward the jets on both the warm and cold sides of the fronts (Mied et al. 1986, Eriksen et al. 1991, Weller et al. 1991, Pollard \& Regier 1992).

Two latitudinal bands of fronts have been observed in the STCZ using satellite imagery of sea surface temperature (Halliwell \& Cornillon 1989, Halliwell et al. 1991, Weller 1991), but the locations and movements of these fronts vary within and among years. Density sections during February or March of 3 different years (Wegner 1982, Kleckner \& McCleave 1988, Pollard \&
Regier 1992), suggest that a northern frontal band is associated with the sigma-t 25.6 isopycnal (Miller \& McCleave 1994). Water with density less than sigma-t 25.6, or southern Sargasso surface water (SSSW), was on the south side of the fronts, and mixed convergence zone water (MCZW) with sigma-t 25.6 to 26.2 was found to the north. The SSSW formed shallow eddies in the MCZW north of the fronts in 1979, 1985 and 1986 (Wegner 1982, Kleckner \& McCleave 1988, Pollard \& Regier 1992, Miller \& McCleave 1994) Another front farther south was associated with the sigma-t 25.0 isopycnal in the SSSW in all 4 years during which the collections used in this study were made (Wegner 1982, Kleckner \& McCleave 1988, Miller \& McCleave 1994). Although the 2 bands of fronts occurred at the same densities in hydrographic sections during winter and spring, the distance between the 2 fronts was varied. 


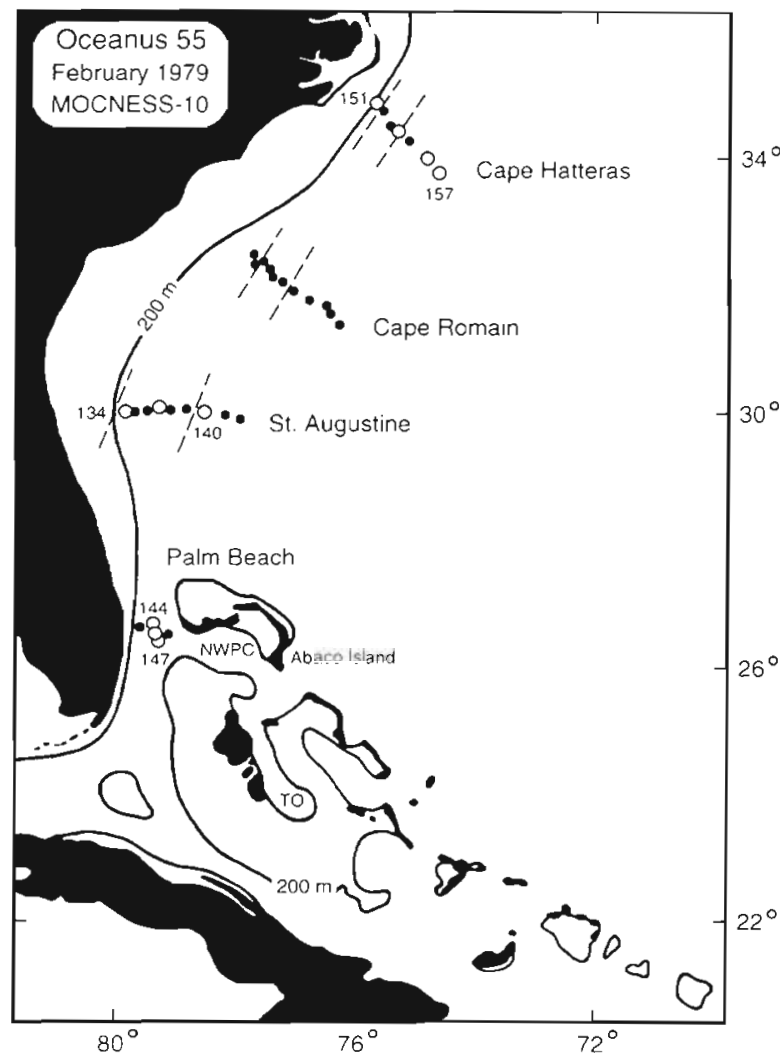

Fig. 2. Station locations of the Oceanus 55 cruise (OC55) in the Florida Current. (0) Assemblage stations, TO: Tongue of the Ocean; NWPC: northwest Providence Channel. Dashed lines indicate regions of greatest surface velocity

Methods. The hydrographic data and a large proportion of the leptocephali used in this study were collected during 5 cruises made by the University of Maine (UM) in the Sargasso Sea. Other leptocephali were collected during 2 cruises (in 1979) made by different institutions. Cruise designations are given in Table 1 The UM collections were made at stations in the vicinity of fronts in the STCZ and around the Bahamas during the February-to-April season of 1981, 1983, 1985 and 1989. The UM across-front transects are designated by cruise abbreviation and a transect label (E, W, N, S) indicating relative location of the transect (Fig. 1a). Cruise CI81 had 26 stations scattered along the northeastern edge of the Bahamas, Hispaniola, Puerto Rico and northward to a front in the southern Sargasso Sea (Fig. 1a) (Kleckner et al. 1983, Wippelhauser et al. 1985). The other 4 UM cruises had
66 stations on 7 transects ( 155 to $611 \mathrm{~km}$ in length), which crossed fronts in the STCZ (Kleckner \& McCleave 1988, Miller \& McCleave 1994), and 3 stations in the Tongue of the Ocean (TO) of the northern Bahamas. Conductivity-temperature-depth (CTD) profiles were made at 63 of the 66 stations of the frontal transects.

At each station, usually 1 (1981, 1983 and 1989) or 2 (1985) tows of a $3 \mathrm{~m}$ Isaacs Kidd Midwater Trawl were used to collect leptocephali. Single oblique tows were made during Cruises CI81, 831 and 85, and double oblique tows were made during Cruises 832 and 89. The maximum depth of the tows ranged from 250 to $400 \mathrm{~m}$ (Kleckner et al. 1983, Kleckner \& McCleave 1988, Miller \& McCleave 1994). The trawl had a mouth area of $8.68 \mathrm{~m}^{2}$, a filtering area of $68.9 \mathrm{~m}^{2}$ and was fully lined with $0.5 \mathrm{~mm}$ NITEX netting.

Time constraints resulted in tows being made both day and night. However, catch rates of the leptocephali of shelf species in the frontal transects were usually lower in day tows than in night tows (Miller \& McCleave 1994), as has been reported previously (Castonguay \& McCleave 1987, Kajihara et al. 1988). To insure the most accurate descriptions and comparisons of species assemblages, only tows that began after sunset and ended before sunrise were used as assemblage stations in the cluster analysis and ordination. The exceptions were the 2 day tows at $\operatorname{Stn} 7$ of the western transect, $85 \mathrm{~W}$, which were included in the analysis because they were unusual in having one of the highest catch rates of shelf species of Cruise 85 (Miller \& McCleave 1994) and were in an important location relative to frontal features not sampled by night tows.

A 1979 German cruise for Anguilla (AD79) sampled a large area in the eastern STCZ (Tesch 1982) and
Table 1. Cruises providing collections of leptocephali used in this study. UM: University of Maine cruises

\begin{tabular}{|c|c|c|c|c|}
\hline Ship/Cruise & $\begin{array}{l}\text { Cruise } \\
\text { abbreviatic }\end{array}$ & Date & $\begin{array}{l}\text { No. of assem- } \\
\text { blage stations }\end{array}$ & $\begin{array}{l}\text { Total no. } \\
\text { of tows }\end{array}$ \\
\hline $\begin{array}{l}\text { 'Anton Dorhn' } \\
210 / 92\end{array}$ & AD79 & $10 \mathrm{Feb}-5 \mathrm{Mar} 1979$ & 19 & 43 \\
\hline $\begin{array}{l}\text { 'Oceanus' } \\
\text { Oc55 }\end{array}$ & OC55 & $10-24$ Feb 1979 & 10 & 35 \\
\hline $\begin{array}{l}\text { 'Columbus Iselin' } \\
\text { Cl8102 (UM) }\end{array}$ & CI81 & 13 Feb-5 Mar 1981 & 9 & 26 \\
\hline $\begin{array}{l}\text { 'Cape Florida' } \\
\text { CF8303 (UM) }\end{array}$ & 831 & $12-19$ Feb 1983 & 8 & 22 \\
\hline $\begin{array}{l}\text { 'Cape Florida' } \\
\text { CF8305 (UM) }\end{array}$ & 832 & 3-14 Apr 1983 & 8 & 18 \\
\hline $\begin{array}{l}\text { 'Cape Florida' } \\
\text { CF8503 (UM) }\end{array}$ & 85 & $15-29$ Mar 1985 & 12 & 47 \\
\hline $\begin{array}{l}\text { 'Columbus Iselin' } \\
\text { CI8901 (UM) }\end{array}$ & 89 & 16-21 Feb 1989 & 4 & 7 \\
\hline
\end{tabular}


had stations in and on both sides of 2 bands of fronts (Wegner 1982). A $3 \mathrm{~m}$ Isaacs Kidd Midwater Trawl with $0.5 \mathrm{~mm}$ netting and a mouth opening of $6.2 \mathrm{~m}^{2}$ was used to collect leptocephali at 42 stations. One oblique tow per station was deployed around sunset or later and fished to a maximum depth that varied from 20 to $375 \mathrm{~m}$ (Schoth \& Tesch 1982, Tesch 1982). To reduce variability in catches due to different fishing depths, only the 17 tows that fished at depths of $100 \mathrm{~m}$ or shallower were used as assemblage stations (Fig. 1b). These tows were selected because the leptocephali of shelf species appear to be most abundant in the upper $100 \mathrm{~m}$ at night (Castonguay \& McCleave 1987, Kajihara et al. 1988, M. J. Miller unpubl.). Tows that fish deeper generally catch fewer leptocephali and are less representative of the assemblage found in a particular area.

'Oceanus' 55 (OC55) was a cruise made by the Woods Hole Oceanographic Institution (WHOI) in February 1979 as part of the mesopelagic fish surveys. This cruise had 35 stations in 4 transects across the Florida Current from the Straits of Florida to Cape Hatteras (Fig. 2). Each transect was 33 to $193 \mathrm{~km}$ in length and had stations in and on each side of the region of the current with the highest speed (J. E. Craddock unpubl.). Collections were made with the multiple opening and closing net and environmental sensing system, or MOCNESS-10 (Weibe et al. 1985), which is a multiplenet midwater trawl with a $10 \mathrm{~m}^{2}$ mouth opening that is designed to fish 5 to 10 discrete depth intervals during each deployment. The trawl had $3.0 \mathrm{~mm}$ circular mesh and was fished at 1 to 6 depth intervals to a maximum depth of at least 300 to $400 \mathrm{~m}$ at each station. Only night tows that fished predominantly in the upper $100 \mathrm{~m}$ with 2 or more depth intervals were used as assemblage stations. Ten night tows in 3 of the transects met these criteria, and the leptocephali from all the depth intervals were pooled for each tow.

Leptocephali collected during the various cruises were fixed in 4 to $10 \%$ seawater-formalin, measured to the nearest millimeter total length, and identified following Smith (1979) and Böhlke (1989). The leptocephali from AD79 were identified and measured by D. G. Smith. Some congeneric species could not be distinguished consistently without risk of misidentification as a result of similar or overlapping myomere ranges, and only the generic identifications of these species (mostly congrids) were used in the analysis. Throughout the analysis, the minimum number of species at a particular station or group of stations will be termed number of species or taxa, even though a few of the taxa (genera) may represent more than 1 actual species

The catch data from various groups of stations were pooled within transects or cruises for the cluster analysis and ordination to allow a more meaningful and manageable analysis of the species assemblages at the 70 assemblage stations. The 32 assemblage stations from the frontal transects were pooled into 13 groups of stations, which will be termed locations. Each transect was split into a north and south location (except for $832 \mathrm{E}$, which was pooled into 1 location) that had low and high catch rates of shelf species, respectively (Fig. 1b). This splitting was based on patterns of catch rates of shelf taxa at individual stations in relation to the positions of fronts and the relationship of these stations in the cluster analysis and ordination of catch rates by Miller \& McCleave (1994). The three 831 stations in the Tongue of the Ocean (831TO) were pooled into 1 location. The 9 CI81 and 19 AD79 assemblage stations were each pooled into 2 locations per cruise (Fig. 1b). For Cruise CI81, the 6 stations north of about $22^{\circ} \mathrm{N}$ were pooled into 1 location (CI81N), and the 3 southernmost stations, which were well away from the front, were pooled into another (CI81S). For Cruise AD79, the 8 stations west of about $62^{\circ} \mathrm{W}$ that were south of the northernmost front (AD79FR) had slightly higher species richness and were pooled. The remaining stations to the north and east were pooled into the second location (AD79NE). The 10 OC55 assemblage stations in the Florida Current were not pooled.

The relationships among species assemblages at stations or locations were examined using agglomerative, hierarchical cluster analysis and non-metric multidimensional scaling (ordination) of species abundances (Field et al. 1982). Prior to analysis, the catch data were transformed using a root-root transformation (Field et al. 1982) to scale the values so the most abundant taxa would not dominate the analysis. The catch data of the 82 tows from 70 assemblage stations were pooled into 28 locations, which were used in the cluster analysis and ordination. The Bray-Curtis measure with the unweighted pair-group method (UPGMA) was used in the cluster analysis. The taxa in the locations included in 4 major designated clusters produced by the cluster analysis were pooled by cluster and these 4 numerical distributions of taxa were compared to each other using a Monte Carlo test (Roff \& Bentzen 1989, McElroy et al. 1992). An ordination of the assemblages at each location was performed with non-metric multidimensional scaling using the same dissimilarity matrix generated for cluster analysis. Multidimensional scaling (MDS) finds the best overall fit of points (assemblages) in 2- or 3-dimensional space based on the dissimilarity values for all pairs of points. The distances in the MDS plot have a monotonic relationship to the original distances, so similar points should be shown close together and dissimilar ones far apart. This plot provides a way to visualize the dissimilarity 
relationships among assemblages at the various locations and can be used to evaluate the results of cluster analysis, which tend to emphasize discontinuities by dividing stations into discrete clusters.

\section{RESULTS}

\section{Species composition of assemblages}

At least 4 groups of similar assemblages of leptocephali of the 5 shelf families were identified by cluster analysis and ordination of data from the 28 different locations that were compared. For descriptive purposes, 4 general assemblages with 2 or more locations were represented by arbitrary designations of major groups of clusters (I to IV) in the dendrogram (Fig. 3). The general cohesion of the 4 designated clusters was supported by the containment of their locations within separate non-overlapping ovals in the MDS plot (Fig. 4). Four locations were excluded from the designated clusters to highlight their different compositions (Table 2). They grouped with either Cluster II or III, but were not directly linked with another location and appeared as partial outliers in the MDS plot. The numerical distributions of abundances of taxa in each of the 4 designated clusters were significantly different

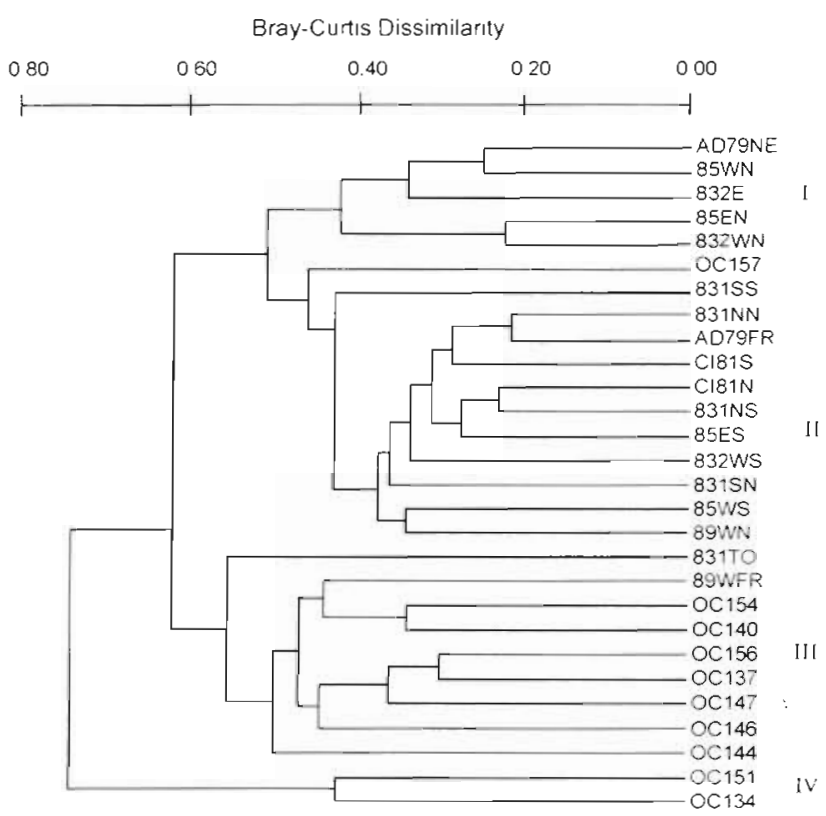

Fig. 3. Dendrogram from cluster analysis of assemblages of leptocephali at 28 locations. Each location represents either several stations within 1 cruise or just 1 station (Cruise OC55 stations and Stn 89WFR) See Figs. 1 \& 2 for designations, positions, and poolings. Shaded bars indicate major cluster designations

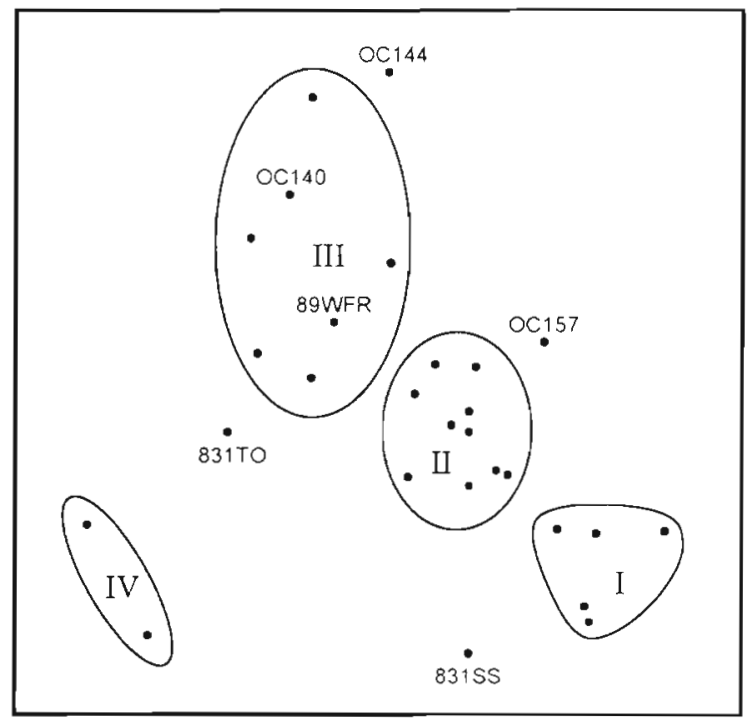

Fig. 4. Multidimensional scaling plot of 28 assemblages of leptocephali. Assemblages of Clusters I to IV (Fig. 3) are shown. The individual location assemblages listed in Table 2 are identified

from each of the other clusters using the Monte Carlo test $(\mathrm{p}<0.001)$

The impoverished assemblages of leptocephali collected north of fronts and in the eastern STCZ were similar in general composition and were identified as Cluster I. The assemblages from Cruise 85 non-frontal stations in the $\mathrm{MCZW}$, stations north of the front in 832W, 832E and non-frontal AD79 stations (AD79NE) comprised this group (Fig. 3). The 26 tows at these 5 locations collected only 14 species of 4 families, with an average of 8.7 species per location. The leptocephali of Ariosoma balearicum and Anarchias similis were most abundant at these locations, but no ophichthids and relatively few species or individuals were collected there (Table 2). Gnathophis and Chilorhinus suensoni were the only other species collected at all 5 locations of Cluster I. The low abundance at these northerly and easterly stations was not sampling bias because several other oceanic species and Anguilla anguilla were relatively abundant at some of these stations (Miller \& McCleave 1994). The few shelf species caught there were also collected at the locations south of the fronts and in the west, which comprised Cluster II.

Similar but more species-rich assemblages were collected at or south of the northern band of fronts and were identified as Cluster II. The 42 tows of these 10 locations were made during 6 cruises. These tows consistently collected Ariosoma balearicum and Anarchias similis, but also collected 7 species of ophichthids and a wider variety of chlopsids, congrids and muraenids 
Table 2. Numbers of leptocephali of each taxon collected at the locations in the 4 major designated clusters, 2 locations included in Cluster III (underlined), and the 4 locations not included in the designated clusters

\begin{tabular}{|c|c|c|c|c|c|c|c|c|c|c|}
\hline \multirow[t]{3}{*}{ Family/Species } & \multicolumn{10}{|c|}{ Cluster groups and locations } \\
\hline & \multirow[t]{2}{*}{ I } & \multirow[t]{2}{*}{ II } & III & \multicolumn{2}{|c|}{ OC $89 w^{2}$} & IV & \multirow{2}{*}{$\begin{array}{l}O C \\
144\end{array}$} & \multirow{2}{*}{$\begin{array}{l}O C \\
157\end{array}$} & \multirow{2}{*}{$\begin{array}{l}831 \\
\text { TO }\end{array}$} & \multirow{2}{*}{$\begin{array}{l}831 \\
\text { SS }\end{array}$} \\
\hline & & & & & & & & & & \\
\hline \multicolumn{11}{|l|}{ Chlopsidae } \\
\hline Catesbya pseudomuraena & & 5 & 1 & 1 & 1 & & & & & 1 \\
\hline Chlopsis bicolor & 4 & 9 & 3 & & 1 & & & & & 1 \\
\hline Chlopsis dentatus & 1 & 5 & 2 & 1 & 1 & & & & & \\
\hline Chilorhinus suensoni & 10 & 85 & 34 & 7 & 21 & & & & 7 & 1 \\
\hline Kaupichthys hyoproroides & 515 & 108 & 41 & 3 & 32 & & & & & 7 \\
\hline Kaupichthys nuchalis & & 4 & & & & & 1 & & & \\
\hline Robinsia catherina & 1 & 3 & 2 & 2 & & & 1 & & & \\
\hline \multicolumn{11}{|l|}{ Congridae } \\
\hline Ariosoma balearicum & 511 & 827 & 557 & 6 & 535 & 367 & 16 & 7 & 14 & 17 \\
\hline Conger oceanicus & 4 & 96 & 45 & 7 & 28 & 8 & & & 2 & 4 \\
\hline Conger triporiceps & 2 & 24 & 8 & 1 & 3 & & 2 & 2 & 3 & \\
\hline Gnathophis spp. & 22 & 46 & 24 & 5 & 8 & 1 & 1 & 3 & 1 & \\
\hline Heteroconger halis & & 2 & 5 & 1 & 1 & & & & 4 & \\
\hline Paraconger spp. & & 1 & 5 & 2 & & 25 & & & & \\
\hline Rhechias dubia & & & 1 & & & 4 & & & 1 & \\
\hline Rhechias thysanochila & & 5 & 1 & & 1 & & & & & \\
\hline Rhechias sp. A & & 3 & 4 & 2 & & & & & & \\
\hline Rhynchoconger spp. & 1 & & 19 & & 1 & 336 & & & & \\
\hline Uroconger syringinus & & 2 & 4 & 3 & & 3 & 1 & & & \\
\hline Xenomystax spp. & & 8 & 8 & 1 & 1 & 4 & & & & \\
\hline Genus C & & & 3 & & & 2 & 3 & & & \\
\hline \multicolumn{11}{|l|}{ Moringuidae } \\
\hline Moringua edwardsi & 1 & 85 & 54 & 10 & 30 & & 55 & 1 & 13 & 1 \\
\hline Neoconger spp. & & & 3 & 2 & & 1 & & & & \\
\hline \multicolumn{11}{|l|}{ Muraenidae } \\
\hline Anarchias similis & 93 & 135 & 6 & 1 & 4 & & 1 & 2 & & \\
\hline Gymnothorax miliaris & 2 & 5 & 4 & & 3 & & 1 & & & \\
\hline Gymnothorax moringa & & 5 & 13 & 7 & 2 & & 27 & & 1 & \\
\hline Gymnothorax ocellatus & & & 2 & 1 & & & 2 & & & \\
\hline Gymnothorax vicinus & & 5 & 13 & 2 & 2 & & 3 & & & \\
\hline Monopenchelys acuta & 1 & 12 & 1 & & 1 & & & & & 2 \\
\hline \multicolumn{11}{|l|}{ Ophichthidae } \\
\hline Ahlia egmontis & & 7 & 16 & 2 & 9 & 10 & & & 10 & \\
\hline Apterichtus ansp & & & 1 & 1 & & & & & 4 & \\
\hline Apterichtus kendalli & & 2 & 7 & 3 & & & 2 & & & \\
\hline Ichthyapus ophioneus & & 1 & 5 & 1 & & & 1 & & 2 & \\
\hline Myrichthys ocellatus & & 1 & & & & & & & 12 & 1 \\
\hline Myrichthys oculatus & & 3 & 1 & & 1 & & & & & \\
\hline Myrophis platyrhynchus & & 2 & 4 & 2 & 2 & 1 & & & 18 & \\
\hline Myrophis punctatus & & 10 & 21 & 3 & 11 & 45 & & & 69 & \\
\hline Ophichthus puncticeps & & & 1 & & & & & & & \\
\hline No. of taxa & 14 & 30 & 35 & 26 & 23 & 13 & 15 & 5 & 15 & 8 \\
\hline No. of tows & 26 & 42 & 7 & 1 & 2 & 2 & 1 & 1 & 3 & 2 \\
\hline
\end{tabular}

location 831SS and the high catch 89WFR location (Figs. 3 \& 4), which was within the southern edge of the front crossed by the westernmost transect (Fig. 1b). The 2 tows of 89 WFR collected relatively large numbers of species characteristic of Cluster II, but they also collected Heteroconger halis and Rhynchoconger spp., which were rare in the STCZ (Table 2).

The richest assemblages were found in the Florida Current and the westernmost frontal station 89WFR. These stations were identified as Cluster III (Figs. 3 \& 4). These 6 Florida Current assemblage stations and 89WFR had an average of 15.2 species per station. At Stn OC140 on the Sargasso Sea side of the St. Augustine transect of OC55 (Fig. 2), 26 species were collected (Table 2), which was the most of any station of this study. The majority of species found at 89 WFR, and a variety of others that were rare or absent in the STCZ, were collected at this station. The other OC55 stations in Cluster III also had a mixture of the common and rare species of the STCZ. Five species were collected only in the Florida Current (Table 2), and taxa such as Heteroconger halis, Paraconger spp., Rhynchoconger spp, and Apterichtus kendalii were collected in several of the OC55 stations of Cluster III, but were in only 1 or 2 of the western tows in the STCZ. Conversely, the chlopsid, Catesbya pseudomuraena, and the muraenid, Monopenchelys acuta, were present in several of the STCZ locations but were absent from the Florida Current. Anarchias similis and, to a lesser extent, Ariosoma balearicum were rare in most of the stations in the Florida Current compared to the STCZ.

The assemblages in the Tongue of the Ocean (831TO) and Stn OC144 (in

(Table 2). Chilorhinus suensoni, Kaupichthys hyoproroides, Moringua edwardsi, Conger oceanicus and Gnathophis spp. were consistently collected throughout the region. A total of 30 species at an average of 11 per station was collected at the 10 locations of Cluster II (Table 2). The only assemblages in the southwestern STCZ that were not included in Cluster II were the low catch and southernmost frontal transect the Straits of Florida) were closely associated with Cluster III (Figs. $3 \& 4$ ), but differed in their compositions of some taxa (Table 2). The assemblage in $831 \mathrm{TO}$ was dominated by ophichthids, but also included 8 other species (Table 2). Myrophis punctatus and Myrophis platyrhynchus were the most abundant of the 6 ophichthid species collected there. In contrast, relatively few ophichthids were collected at Stn OC144, 
but more specimens of Moringua edwardsi, Gymnothorax moringa and Genus C 2 species of congrid leptocephali described by Smith (1989b) which are not matched to adult forms] were collected at this station than at any other (Table 2). Based on velocity sections in this region of the Florida Current (Niiler \& Richardson 1973, Leaman et al. 1987), this station was probably in the eastern edge of the strongest flow.

At the westernmost stations of the St. Augustine and Cape Hatteras transects across the Florida Current assemblages were collected that probably originated in the Gulf of Mexico and are identified in the dendrogram as Cluster IV (Fig 3). These 2 assemblages were characterized by relatively large numbers of Ariosoma balearicum, Rhynchoconger spp., Paraconger spp. and Myrophis punctatus but did not contain any chlopsids muraenids or Moringua edwardsi (Table 2). The largest numbers of Rhynchoconger spp. and Paraconger spp. of this study, as well as 334 specimens of $A$, balearicum, were collected at the westernmost station of the St. Augustine transect (OC134). Although not all of the Rhynchoconger spp. at Stn OC134 were identified to species, most were probably R. flava (M. J. Miller unpubl.). The Rhynchoconger spp. collected in the Florida Current were similar in size to that reported during spring in the Gulf of Mexico where it is one of the most abundant leptocephali (Smith 1989b). Myrophis punctatus and Paraconger spp. are also relatively abundant in the Gulf of Mexico (Leiby 1989, Smith 1989b). A Gulf of Mexico origin of these leptocephali is plausible because water from the Gulf of Mexico has been identified in the western Florida Current (Wennekens 1959, Schmitz et al. 1993).

The leptocephali of Ariosoma balearicum at Stn OC134 had a size range (Fig. 5 b) similar to that reported in the Gulf of Mexico in. February (Smith 1989b). This species appears to have low and high myomere count forms, which are distinguished by partially overlapping ranges of total number of myomeres and by different adult distributions (Smith 1989b, c). The adults of the low-count form are found in the Bahamas, the Caribbean and the Gulf of Mexico, while the 2 high-count populations are located along the southeast coast of North America, between southern Florida and Cape Hatteras, and along the northeast coast of South America (Smith 1989c). The leptocephali in the wostern Florida Current were predominantly the low-count form with a contrasting length distribution (Fig. 5) compared to the high-count form, which predominated in the STCZ during this season (M. J Miller unpubl.). This contrast in the relative abundance of length classes between the 2 regions, and the composition of other species in the western Florida Current, indicate that the lowcount $A$. balearicum caught there were probably from the Gulf of Mexico.

\section{Species richness in relation to water density in the STCZ}

The two $611 \mathrm{~km}$ north-south transects of Cruise 85 provided the best comparison between assemblages in SSSW and MCZW because they crossed the northern front separating the 2 water types. There were consistently more species collected in stations at or south of this front than there were to the north. Transect $85 \mathrm{~W}$ crossed a large eddy of this front, which contained a small pool of SSSW separated by MCZW, from the SSSW to the south (Fig. 6a). Day tows of Stn 7 in the SSSW core of this eddy collected more species than any other Cruise 85 station. Stn 6 in MCZW was south of the northernmost front associated with this eddy, and almost as many species were collected there as at $\operatorname{Stn} 7$. The stations in the eddy and the 2 southermmost stations

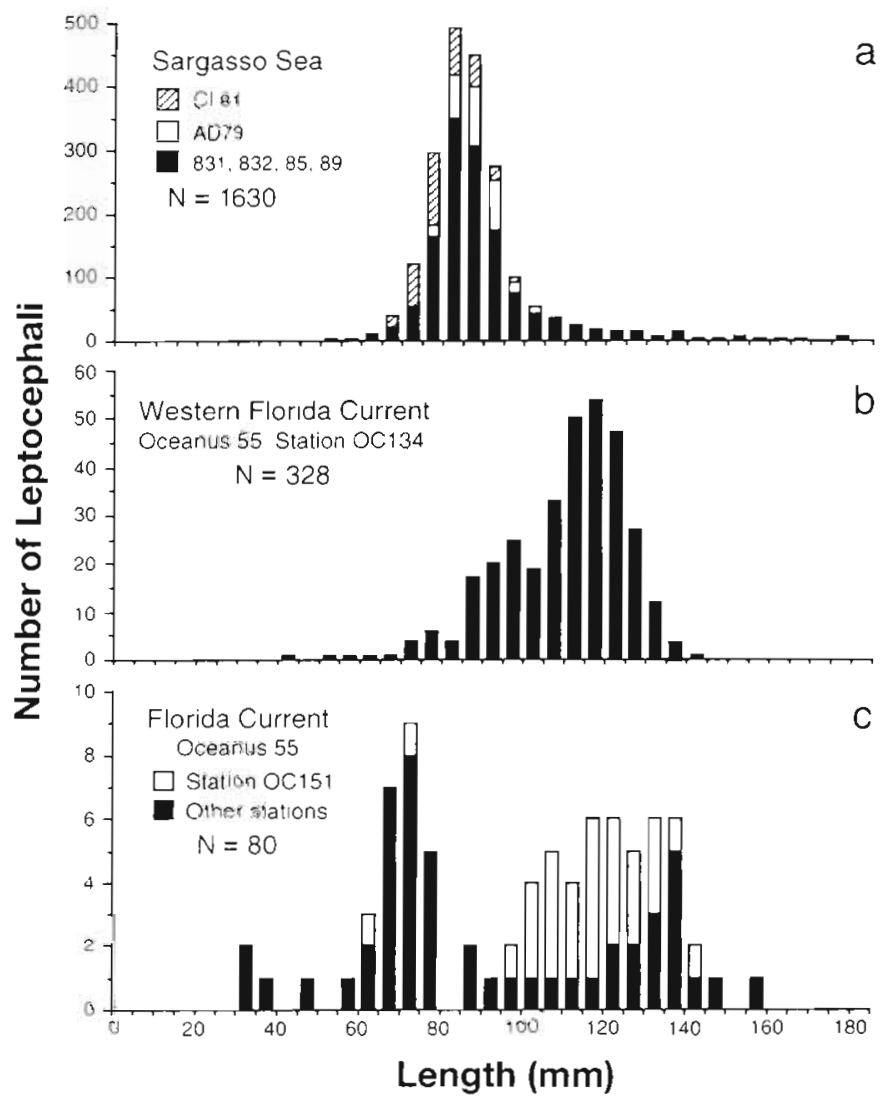

Fig. 5. Anosoma balearicum. Length frequency distributions in (a) the Sargasso Sea during February, March and April of 5 different years from (see Table 1 for cruise names and years); (b) the western Florida Current at Stn 134 of Cruise OC55; and (c) the western Florida Current at Stn 151 and other stations of Cruise OC55 in the Florida Current in February 1979 

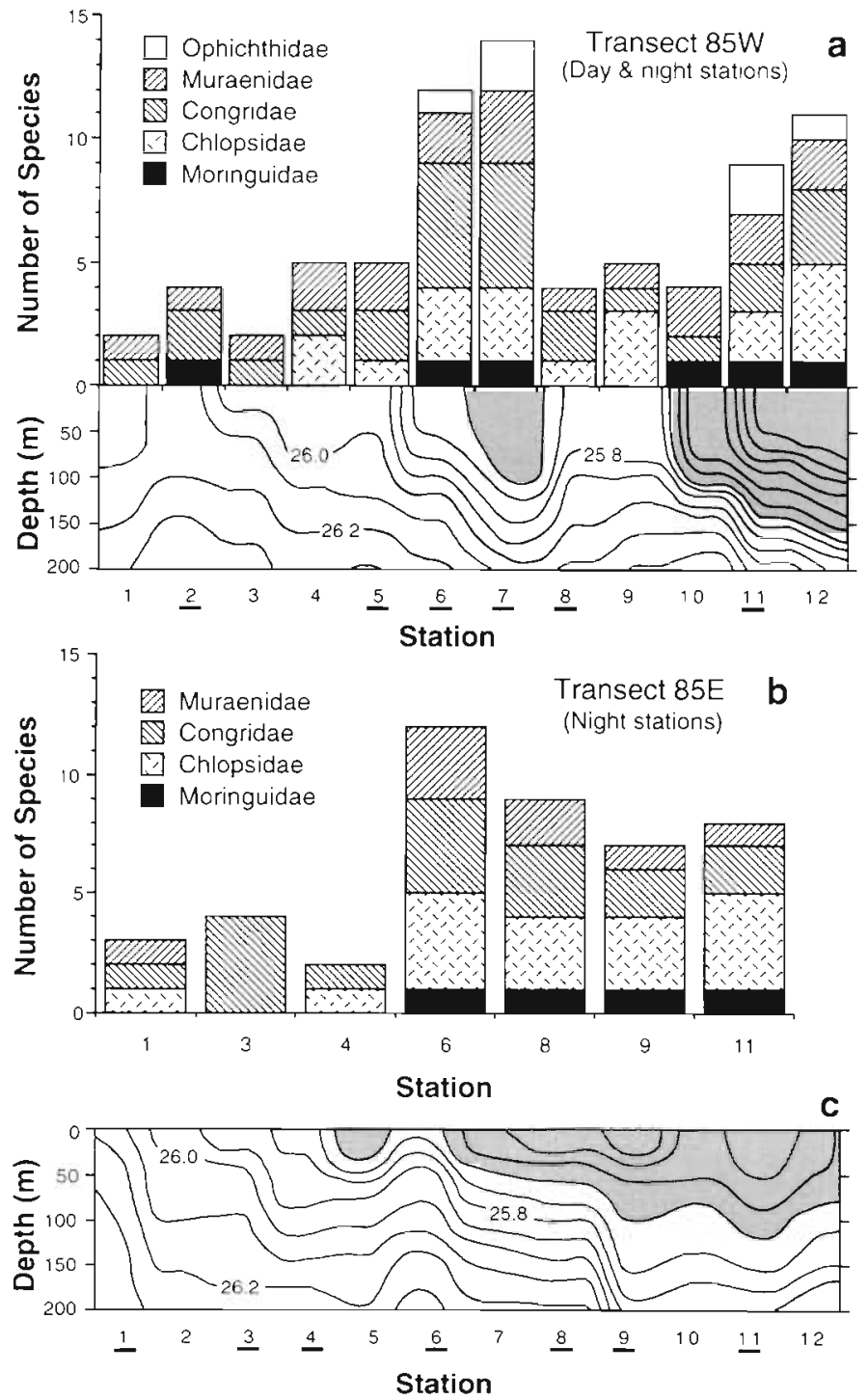

Fig. 6. (a) Number of taxa per family at each station along Transect $85 \mathrm{~W}$ (see Fig. 1) superimposed on density contours (isopycnals) along the transect. (b) Number of taxa per family at each night station (day stations are excluded) along $85 \mathrm{E}$. (c) Density contours along Transect $85 \mathrm{E}$. In (a) and (c) shading indicates SSSW (sigma-t $<25.6$ ), and assemblage station numbers are underlined. North is to the left in all panels

in the southern pool of SSSW had about twice the average number of species than did the MCZW stations north of the front and between the 2 pools of SSSW (Fig. 6a). Stns 6, 7, 11 and 12 were the only stations where ophichthids were collected (Fig. 6a). This pattern of higher species richness associated with the distribution of SSSW along the transect was also seen in the distribution of catch rates of leptocephali of the 5 shelf families along this transect (Miller \& McCleave 1994). A similar pattern of species richness (Fig. 6b) and catch rate (Miller \& McCleave 1994) was seen along 85E, but the eddy of SSSW was much smaller in this transect (Fig. 6c) and it was only sampled during the day. The greatest number of species in $85 \mathrm{E}$ was collected at Stn 6, which, based on density and velocity sections across similar fronts in this region (Eriksen et al. 1991, Weller et al. 1991, Pollard \& Regier 1992), was close to the likely location of a frontal jet. An average of 9 species was collected at the 4 night stations at or south of the front, but only an average of 3 species was collected at the 3 night stations in MCZW north of the front.

The shorter $89 \mathrm{~W}, 831 \mathrm{~N}, 831 \mathrm{~S}$ and $832 \mathrm{~W}$ transects crossed fronts associated with the 25.0 isopycnal (Fig. 1b) but did not extend far enough north to reach the transition between MCZW and SSSW (Kleckner \& McCleave 1988, Miller \& McCleave 1994). However, a similar though less distinct pattern of greater richness and abundance of leptocephali at or south of these fronts was apparent. The 2 tows of $89 \mathrm{WFR}$ at the southern end of $89 \mathrm{~W}$, were within the southern edge of the front and collected more species $(n=23)$ and larger numbers of several shelf species than any other station in the STCZ (Table 2). The 2 night tows north of the front collected 13 species. The other short transects also showed a general pattern of greater number of species at or south of the fronts, as well as indications of discontinuities in catch rates of shelf species across these fronts (Miller \& McCleave 1994). However, the distributions of night tows in some transects was not optimum for comparing the assemblages on both sides of the fronts.

Cruise AD79 sampled a large area of the STCZ east of most frontal transects and had 8 assemblage stations in MCZW and 11 in SSSW. The SSSW stations were on both sides of the surface expression of the 25.0 isopycnal (Fig. 1b), which was also associated with the southern front in 1979 (Wegner 1982). Three of the 8 westernmost SSSW stations were just south of the northern front and the other 5 were associated with the southern front. These westernmost SSSW stations were the only AD79 stations where either Conger oceanicus or Moringua edwardsi were collected, with both being collected at 3 stations. All 8 stations were pooled into the AD79FR location (Fig. 1b) based on their westerly locations and close proximity to the south side of fronts. The 3 easternmost SSSW stations were pooled with the $8 \mathrm{MCZW}$ stations into the AD79NE location. The stations of AD79NE averaged 4 species per station (13 total), compared to 6 species per station (14 total) for AD79FR. The greatest number of species at any station of this cruise was 8 , and these were caught at one of the AD79FR stations close to the northern front. 


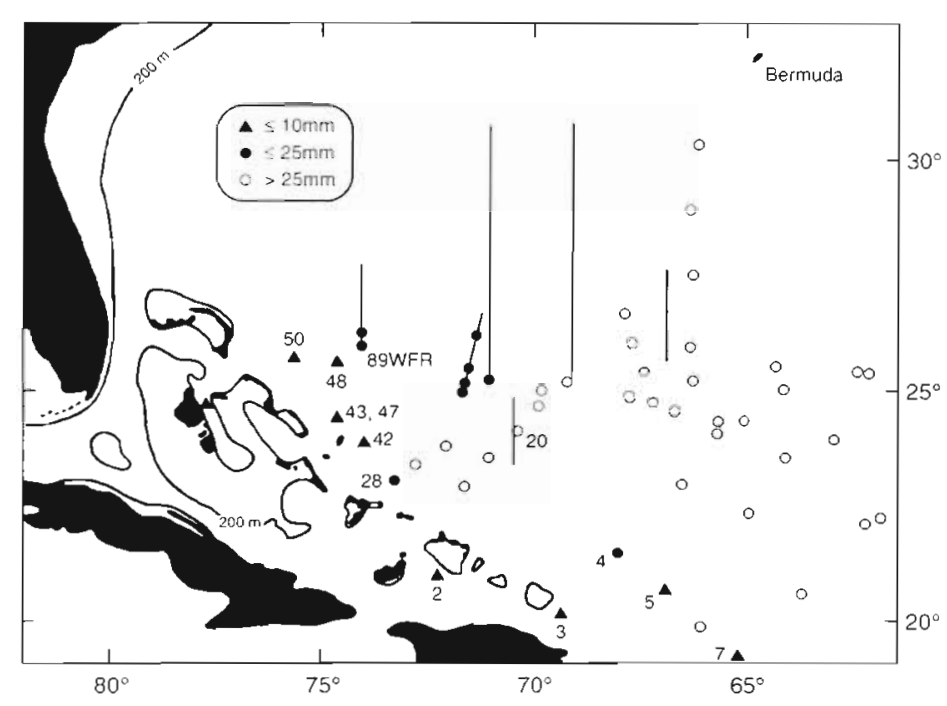

Fig. 7. Stations where shorter length classes of leptocephali (other than Conger oceanicus) were collected. (₫) Stations with at least 1 specimen $\leq 10 \mathrm{~mm}$; $(\bullet)$ stations with at least 1 specimen $\leq 25 \mathrm{~mm}$; (아 stations with at least 1 specimen $>25 \mathrm{~mm}$. In numbered stations are from Cruise Cl81 (see Fig. 1)

The greatest numbers of species in CI81 were collected at Stn 50 east of Little Bahama Bank and at Stn 20 (Fig. 7), which was located farther offshore and was the station closest to the temperature front shown by Kleckner et al. (1983). At Stn 20, 11 species were collected, including the largest single station catch of Conger oceanicus $(n=45)$ of this study. Almost all of the other stations of this cruise were south of this front, which was probably at the 25.0 isopycnal, based on temperature-density correlation. Stn 50 was not as close to the front, but it was the closest station to the mouth of the northeast Providence Channel of the northern Bahamas, in a region often characterized by northwesterly water flow. There were 12 species collected at this station, and it had the largest catch of Moringua edwardsi ( $\mathrm{n}=9$ ) and the second largest catch of Conger oceanicus $(n=9)$ of CI81. At least 6 species were collected at each of the other assemblage stations of Cl81, but Stns 20 and 50 were the only ones at which at least 1 species of all 5 families was collected.

\section{Distribution of small leptocephali}

The collections in the STCZ and Tongue of the Ocean were made with an IKMT with $0.5 \mathrm{~mm}$ netting, which is capable of catching recently hatched leptocephali. The 3 tows made in the Tongue of the Ocean collected a total of 35 specimens that were $\leq 25 \mathrm{~mm}$. Most of the small specimens belonged to 4 species of ophichthids, although 2 congrids, Heteroconger halis $(25 \mathrm{~mm})$ and Rhechias sp. $(17 \mathrm{~mm})$, and Moringua edwardsi ( 17 and $23 \mathrm{~mm}$ ) were also caught there. Fifteen Ahlia egmontis ( 9 to $21 \mathrm{~mm}$ ), 6 Myrichthys ocellatus (8 to $25 \mathrm{~mm}$ ), 5 Myrophis punctatus (9 to $24 \mathrm{~mm}$ ) and 4 Myrophis platyrhynchus (8 to $23 \mathrm{~mm}$ ) were collected (Fig. 8e). Ophichthids $\leq 10 \mathrm{~mm}$ were collected in all 3 tows in the Tongue of the Ocean. In contrast, only a small percentage of the tows in the STCZ and southern Sargasso Sea caught leptocephali $\leq 25 \mathrm{~mm}$, and those that did were generally in the CI81 stations close to the Bahama Banks or in the southern ends of the westernmost frontal transects (Figs. $7 \& 8 f$ ). Leptocephali $\leq 25 \mathrm{~mm}$ from 7 species were collected in the frontal transects, but only Conger oceanicus had specimens $<14 \mathrm{~mm}$. At the 4 stations south of the front in $831 \mathrm{~N} 3$ Myrophis punctatus (17 to $20 \mathrm{~mm}$ ), 2 Moringua edwardsi ( 14 and $18 \mathrm{~mm}$ ) and $6 \mathrm{C}$. oceanicus (8 to $22 \mathrm{~mm}$ ) were collected. Two specimens of Gnathophis spp. (18 and $25 \mathrm{~mm}$ ) were caught north of the front in $831 \mathrm{~N}$. Just to the east in Stn 11 of Transect $85 \mathrm{~W}, 3$ specimens of Ahlia egmontis (16 to $22 \mathrm{~mm}$ ) were collected. To the southeast in $831 \mathrm{~S}$, the only small specimens were 4 C. oceanicus ( 7 to $23 \mathrm{~mm}$ ). Small leptocephali of C. oceanicus (12 mm), A. egmontis $(23 \mathrm{~mm})$ and Chilorhinus suensoni $(25 \mathrm{~mm})$ were collected at $89 \mathrm{WFR}$, which was at the southern edge of the front. A small specimen of Conger triporiceps (19 mm) was collected in a day tow close to this same front. Although several species of oceanic eels were spawning offshore in the Sargasso Sea (Miller \& McCleave 1994), most leptocephali of shelf species were of a consistently large size there (Fig. 8b).

Most leptocephali collected at the CI81 stations were large, but 54 specimens of 4 families were $\leq 25 \mathrm{~mm}$ in length. Almost all these small leptocephali were collected at the stations along the southern edge of the Sargasso Sea (Figs. $7 \& 8$ f). The largest catch was at Stn 3, which was between the easternmost Bahama bank and the eastern end of Hispaniola. There were 17 muraenids ( 5 to $23 \mathrm{~mm}$ ) and 7 ophichthids ( 6 to $11 \mathrm{~mm}$ ) collected there. In addition, leptocephali of Moringua edwardsi $(10 \mathrm{~mm})$ and Conger triporiceps $(10 \mathrm{~mm})$ were collected at this station. Other small ophichthids were collected to the east, at Stn $7(10 \mathrm{~mm})$ and to the northwest, at Stns $42(10,12 \mathrm{~mm}), 43(10,11 \mathrm{~mm})$, $47(8 \mathrm{~mm})$ and $50(4,5,6 \mathrm{~mm})$, which were the stations closest to the northern Bahamas (Fig 7). Small muraenids were also collected at Stns $42(6 \mathrm{~mm})$ and 47 ( $9 \mathrm{~mm}$ ), and 2 congrids (Rhechias spp.) were collected at Stn $48(6,16 \mathrm{~mm})$. Small leptocephali of 
Conger oceanicus were caught at Stns $7(13 \mathrm{~mm})$, 20 (13 mm) and $47(16 \mathrm{~mm})$. Conger spp. leptocephali. probably $C$. triporiceps, were also collected at Stns 2 $(6,12 \mathrm{~mm}), 4(12 \mathrm{~mm}), 5(7,9 \mathrm{~mm})$, and $28(11 \mathrm{~mm})$ along the southern edge of the Sargasso Sea (Fig, 8).

The mesh size of the MOCNESS-10 was too large to retain recently spawned leptocephali, but it did collect leptocephali as small as $15 \mathrm{~mm}$. There were 56 leptocephali of 10 species that were 15 to $25 \mathrm{~mm}$ in length collected in the Florida Current using this trawl, and despite the larger mesh size, the length distributions of several taxa were shorter than those of leptocephali collected in the STCZ (Fig. 8b, c, d). The small leptocephali in the Florida Current were collected at 5 assemblage stations and 8 of the other 25 stations. Of these small specimens, 38 were Moringua edwardsi (20 to $25 \mathrm{~mm}$ ). Small specimens of this species were collected at 10 different stations, but Stn OC144 in the Palm Beach transect (Fig. 2) caught 22 of the total 38. Other than Moringua edwardsi, only
Kaupichthys hyoproroides $(\mathrm{n}=3$ ) and Gnathophis spp ( $\mathrm{n}=5$ ) had more than 2 specimens $\leq 25 \mathrm{~mm}$ in length (Fig. 8c, d). The 3 smallest leptocephali collected during Cruise OC55 were a 15 and an $18 \mathrm{~mm}$ Neoconger spp. and a $19 \mathrm{~mm} K$. hyoproroides.

\section{DISCUSSION}

\section{Spawning locations of shelf eels}

Relatively little is known about the reproductive ecology of shelf eels, largely due to their fossorial and often nocturnal behavior. Most eels are rarely seen, but there have been a few observations of reproductive behavior in some species of shelf eels (Thresher 1984). Large numbers of the ophichthid eel Ahlia egmontis were observed during an apparent spawning migration across the shelf toward deeper water near Honduras in the Caribbean (Cohen \& Dean 1970). Two species of moray eels have been observed spawning in the Pacific Ocean. Gymnothorax herrei was observed moving inshore and spawning at a depth of $\leq 1 \mathrm{~m}$ in the Philippines (Ferraris 1985) and Gymnothorax kikado was observed spawning near southern Japan at a depth of $12 \mathrm{~m}$ (Moyer \& Zaiser 1982). In addition, various genera of moray eels have been found to have a wide range of gonadal morphologies and apparent reproductive strategies (Fishelson 1992). These observations suggest that a variety of spawning tactics may be used by the diversity of shelf eels that inhabit the Bahama Banks, other shelf areas in the region and in these types of tropical and subtropical habitats worldwide.

The geographic distribution of the smallest leptocephali collected in this study indicated shelf eels (except for Conger oceanicus) were spawning close to the Bahama Banks during January and February. Relatively young leptocephali ( $\leq 10 \mathrm{~mm}$ ) of all 5 families except Chlopsidae were collected at the stations closest to the Bahama Banks but not farther offshore (Fig. 7). Although sampling close to the banks was limited to February in this study, similar collections offshore and close to the northern Bahamas in summer and fall found the same general size structure and pattern of occurrence of smaller leptocephali close to the Bahamas and in the Florida Current as opposed to offshore in the STCZ (M. J. Miller unpubl.).

The greatest catch of small leptocephali
Fig. 8. Length frequency distributions of (a) Conger oceanicus, from all 7 cruises, (b) 3 taxa from offshore areas of the Sargasso Sea during 6 cruises, excluding Cruise Cl81 tows close to the Bahamas (specimens not visible: 14 and $18 \mathrm{~mm}$ Moringua edwardsi, $25 \mathrm{~mm}$ Chilorhinus suensoni), (c) Gnathophis spp. from all 7 cruises, (d) 3 taxa collected with the MOCNESS-10 ( $3 \mathrm{~mm}$ mesh size) in the Florida Current during Cruise OC55, (e) 3 species of ophichthids from the Tongue of the Ocean and (f) 4 taxa from Cruise Cl81 Stations 2 to 7 in the southern Sargasso Sea that were excluded from (b) 
was at a station in the northwest Providence Channel of the northern Bahamas, and several of the common species in the Sargasso Sea had much smaller size classes there (Miller 1993) than those collected offshore. A consistent pattern of the smallest leptocephali being collected at the stations closest to the Bahama Banks was apparent in both seasons. Small leptocephali of a variety of shelf species also have been collected close to or over the shelf in the Gulf of Guinea, but not farther offshore (Blache 1977). More intensive sampling is needed to determine when shelf eels spawn and whether different taxa spawn over the shelf, at the edge of the shelf or over deep water.

In this study, Conger oceanicus was the only species that appeared to be spawning well out into the STCZ, and evidence of this activity was largely restricted to the southwest stations associated with the southern band of fronts during February (McCleave \& Miller 1994). Other than C. oceanicus, there were no leptocephali $<15 \mathrm{~mm}$ collected in the STCZ. Those nonConger spp. leptocephali that were 15 to $25 \mathrm{~mm}$ in length were only collected in close association with the southern frontal band crossed by the westernmost transects $85 \mathrm{~W}, 831 \mathrm{~N}$ and $89 \mathrm{~W}$. Based on age and growth analyses of Anguilla spp. leptocephali, which have been estimated to grow from 5.3 to $11.4 \mathrm{~mm} \mathrm{mo}^{-1}$ in the Atlantic (Boëtius \& Harding 1985, Kleckner \& McCleave 1985, Castonguay 1987), the smallest nonConger spp. leptocephali collected in the STCZ may have been more than 6 wk old. Although this region has not been extensively sampled in all months, the size structure and location of small leptocephali in the STCZ during the February-to-April season suggested that most of the leptocephali examined in this study originated outside the STCZ, from the west or southwest.

\section{Influence of circulation on distributions of leptocephali}

Due to the dynamic circulation around the Bahama Banks, when and where shelf eels spawn in relation to these banks may have a significant effect on how their leptocephali are distributed in the region. The large banks of the northern Bahamas separate the Florida Current, as it flows northward through the Straits of Florida, from the more variable circulation of the southern Sargasso Sea. The Florida Current is strong in this region (Niiler \& Richardson 1973, Leaman et al. 1987, Schott et al. 1988) and appears occasionally to form a counter-current to the south along the southwest edge of the Little Bahama Bank, which flows into the northwest Providence Channel (Leaman \& Molinari 1987). This results in eastward flow of surface water in the north and westward flow in the southern part of the channel. However, flow in the opposite directions on the northern and southern sides of the Providence Channel has been observed in March (Richardson \& Finlen 1967), suggesting the flow patterns of surface water through this channel may fluctuate on seasonal or shorter time scales. Midchannel tows in the northwest Providence Channel in October collected large numbers of many shelf species (Miller 1993), so these flow patterns could determine whether leptocephali in this region are transported into the eastern edge of the Florida Current or into the western STCZ.

In the STCZ, the close associations of the most diverse assemblages with both frontal bands support the hypothesis that these fronts transport leptocephali from the west into offshore waters. Convergence of surface water from the south or west may concentrate leptocephali at fronts, especially in the west, where the southern frontal band is closest to the northern Bahamas. Although some species show evidence of vertical migration, catches of leptocephali are greatest in the upper $100 \mathrm{~m}$ (Schoth \& Tesch 1984, Castonguay \& McCleave 1987, Kajihara et al. 1988, M. J. Miller unpubl.) where these fronts are most distinct. Most leptocephali are probably capable of basic depth regulation, which would make them susceptible to convergence of water toward fronts (Olson \& Backus 1985) and result in the concentration of leptocephali at fronts. The probable southwest origin of most species of leptocephali and their concentration in frontal jets by convergence, with limited mixing across them, would account for the separation of the assemblages in the STCZ into 2 general assemblages in the dendrogram and MDS plot (Figs. $3 \& 4$ ). The assemblages of Cluster I were farthest north and east and included the impoverished assemblages collected in MCZW or away from fronts in SSSW. The locations of Cluster II had stations at or south of both bands of fronts, with the greatest catches in association with fronts.

The pattern of 2 bands of fronts in the STCZ (Böhm 1988, Halliwell et al. 1991, Weller 1991) and the correlation of these 2 bands with the 25.6 and 25.0 isopycnals, or their temperature correlate, in 1979 (Wegner 1982), 1981 (Kleckner et al. 1983, Tesch \& Wegner 1990), 1983 and 1985 (Kleckner \& McCleave 1988), 1986 (Pollard \& Regier 1992) and 1989 (Miller \& McCleave 1994), suggest that a consistent pattern of 2 frontal bands forms at these 2 densities during this season on a yearly basis. This pattern and the long duration of the leptocephalus stage could result in the consistent formation of 2 bands of diverse assemblages in the STCZ made up of leptocephali transported to the east within the fronts.

Leptocephali may be transported out into the STCZ by an anticyclonic circulation cell located just north- 
east of Abaco Island on the Little Bahama Bank (Fig 2). This circulation cell has been indicated by single season surveys of the area (Gunn \& Watts 1982 , Olson et al. 1984) and in analyses of hydrographic data compiled from several years (Stommel et al. 1978. Olson et al. 1984). The flow structure off Abaco (Rosenfeld et al. 1989, Lee et al. 1990) and transport contours for the same region (Fiadeiro \& Veronis 1983) are consistent with an anticyclonic circulation cell in this region. These studies showed a northwest flow close to Abaco and a southeast flow farther offshore. The northwesterly surface flow observed just east of Abaco in March (Costin 1968) and over longer periods (Rosenfeld et al. 1989, Lee et al. 1990) is consistent with the traditional idea of an Antilles Current flowing to the northwest through the southern Sargasso Sea. Maps of dynamic topography (Stommel et al. 1978, Olson et al. 1984) and models of circulation in the region (Böning et al. 1991) also indicate northwesterly flow in this area. However, the continuity of the Antilles Current has been questioned (Ingham 1975 , Olson et al. 1984), and the existence or strength of flow off Abaco may be correlated with the timing of meanders of a deep western boundary current that flows to the south just off Abaco at depths of about 1000 to $4500 \mathrm{~m}$ (Lee et al. 1990) or with the dynamics of the circulation cell. The location of the northeast side of this circulation cell is close to the locations of southern frontal bands observed during February in 1981 (Kleckner et al. 1983), 1986 (Halliwell et al. 1991) and 1989 (Fig. 1b).

A circulation cell in this location would probably transport leptocephali from the eastern edge of the northern Bahamas into the eddy region to the north and into the western edge of the frontal bands. This mechanism is consistent with the diverse assemblages close to fronts in the western transects and the grouping of the westernmost frontal location 89WFR with the Florida Current stations of cluster III. The close proximity of 89 WFR to the average location of the circulation cell northeast of the northern Bahamas and the likelihood that the Florida Current may transport a similar assemblage of leptocephali northward, away from the northern Bahamas, may account for the similarity between these assemblages.

It is unclear whether leptocephali transported northward by the Florida Current are recirculated into the STCZ, because the circulation north of the Bahamas along the western edge of the Sargasso Sea is not well documented. Variable patterns of alternating north and south flow have been described from transects across this region (Amos et al. 1971, Ingham 1975). Warm outbreaks or intrusions of Gulf Stream water southward into the western Sargasso Sea occur regularly in the region off Cape Hatteras where the Gulf
Stream turns to the northeast (Vukovich \& Crissman 1978, Cornillon et al. 1986, Pratt et al. 1991). These outbreaks and cold core rings that are cast off the Gulf Stream usually move to the south (Lai \& Richardson 1977) and appear to recirculate water into the region north of Abaco. The circulation in this region is probably dominated by eddies resulting in recirculation from the Florida Current and Gulf Stream inter. acting with the northwesterly flow east of Abaco and the western ends of fronts that extend into the STCZ.

The assemblage structure in the Florida Current observed in this study indicated that assemblages from different areas were present and were probably mixing. The long duration of the leptocephalus stage provides the potential for long distance drift into the Gulf Stream system from the Caribbean, Gulf of Mexico and Sargasso Sea. However, it appears that leptocephali of some species collected in the Florida Current, which are virtually absent from the STCZ, are transported north by the Florida Current away from any adult habitat other than Bermuda. Long distance transport of leptocephali creates the potential for recruitment into areas far from the original parental habitat, but mechanisms controlling metamorphosis of leptocephali into juvenile stages are not known.

\section{Life history implications}

The southern Sargasso Sea is well documented as the spawning and larval development area for Anguilla spp., but it is also used by other eels (McCleave 1993, Miller \& McCleave 1994). In addition to a variety of oceanic species, it appears to be the spawning and development area for Conger oceanicus that lives along the east coast of North America (Schmidt 1931, McCleave \& Miller 1994). The life histories of the American eel Anguilla rostrata, whose leptocephali leave the southern Sargasso Sea and cross the Florida Current/Gulf Stream and of the Japanese eel Anguilla japonica, which cross the Kuroshio Current in the Pacific (Tsukamoto 1992), demonstrate that cross-current recruitment mechanisms are possible. The onset of diel vertical migration has been proposed as a mechanism facilitating northward transport of A. japonica leptocephali into the Kuroshio (Kimura et al. 1994), and the northwesterly flow east of Abaco in the Sargasso Sea has been proposed as an important mechanism for transporting $A$. rostrata leptocephali into the Florida Current (McCleave \& Kleckner 1987). However, the mechanisms used by these species to enter and cross the Kuroshio and Florida Current/Gulf Stream remain to be determined (McCleave 1993).

Although several species use the Sargasso Sea as a larval development area, it is unclear whether the 
leptocephali of shelf species whose adults inhabit the northern Bahamas have similar mechanisms for using offshore waters before returning to the banks. In the Sargasso Sea, distinct fronts reaching the surface weaken and move northward in the summer when the surface waters warm (Böhm 1988, Halliwell et al 1991). A weakening of the convergence that maintains the 2 bands of diverse assemblages would release these leptocephali into the pool of warm water in the southern Sargasso Sea. A westerly flow of surface water would then return leptocephali to the northern Bahamas or transport them into the Florida Current Conversely, it may be impossible for the majority of these leptocephali to return to the banks, and they would be a loss to recruitment.

Although it is impossible to determine if leptocephali from the STCZ recruit back to the Bahama banks, there are indications that at least 1 other shelf species uses the Sargasso Sea as a larval development area. Ariosoma balearicum and Anarchias similis were the most abundant shelf species in the northern and eastern STCZ and these 2 species differed somewhat from the general pattern of greater abundance at or south of fronts shown by Anguilla spp. and other shelf species (Miller \& McCleave 1994). This may be related to the fact that they both have adult populations along the southeast coast of North America (Smith 1989c, Böhlke et al. 1989). If the locations or timing of spawning of eels from these areas is different than the eels from the northern Bahamas, different transport mechanisms could result in more of their leptocephali in MCZW and in the eastern STCZ. There is no evidence that these east coast eels spawn in the colder slope water west of the Florida Current, so it is possible that they migrate to an area east of the Florida Current to spawn. Most of the $A$. balearicum leptocephali collected in the STCZ during this study were the high-count form (Smith 1989b, M. J. Miller unpubl.), whose adults in the regions bordering the Sargasso Sea region appear to be restricted to the southeast coast of North America (Smith 1989c). This suggests that the high-count adults of this species spawn somewhere east of the Florida Current and use the Sargasso Sea and Gulf Stream recirculation system (Worthington 1976, McWilliams 1983) as a developmental area for their leptocephali, which then must cross the Florida Current to recruit. In contrast, low-count leptocephali are most abundant close to the Bahamas (M. J. Miller unpubl.), which appear to be inhabited by low-count adults (Smith 1989c). This suggests that the low-count form uses a strategy of larval retention that keeps their leptocephali close to the Bahama banks. A similar retention strategy appears to be used by ophichthid eels, whose leptocephali were very abundant in the Tongue of the Ocean stations, but rare offshore in the STCZ.
There seems to be a great potential for species- or population-specific adaptations for spawning or larval recruitment among shelf species. Different strategies for spawning location, duration of the leptocephalus stage, semelparity and iteroparity have probably evolved in various eel taxa, with 1 of the major selective forces being the location of adult habitats in relation to regional and seasonal flow patterns of surface waters. The influences of geography and physical oceanographic processes on the early life history stages have been proposed as the major determinants of population richness and abundance for marine fishes (Sinclair 1988), and they may be especially important for eels, which appear to have a long larval duration. Some spawning tactics would favor near shore retention of leptocephali and others offshore transport in larger retention areas or oceanic gyres. It is also possible that population-specific orientation mechanisms have evolved in some species of leptocephali that facilitate retention close to, or recruitment back to, adult habitats through directional swimming. These mechanisms may be especially important for populations living in habitats close to strong currents and in the Pacific where there are a larger number of relatively isolated island groups

However, other than for Anguilla spp. and perhaps Conger spp., it is impossible to conclude how speciesor population-specific spawning tactics have been shaped by the geographic and hydrographic conditions of a particular region. First we must gain a better understanding of spawning locations and times, larval durations, growth rates and the factors affecting metamorphosis of various taxa of leptocephali. In the western North Atlantic, more collections throughout the year, around and to the north of the Bahama Banks and in the western frontal zones, are needed to understand the relationships among the life histories of shelf eels and the dynamic patterns of surface water circulation in the region

Acknowledgements. I especially thank James McCleave for sparking my interest in leptocephali, for use of his collections of leptocephali and for his guidance and helpful discussions throughout the project. I thank David Smith for providing the catch data from the 'Anton Dorhn' cruise and acknowledge his years of diligent work on the identifications of leptocephal in the WNA which have made this study possible. I thank Karsten Hartel for facilitating access to the WHOI collections, James Craddock for providing information about 'Oceanus 55', Debbie Krupke and Leslie Bourassa for assistance with specimen work and Steve Parker for working on graphics. This study was supported in part by the Center for Marine Studies and the Migratory Fish Research Institute. Unversity of Mane. The collection of leptocephali and hydrographic data during University of Maine cruises was supported by National Science Foundation grants (OCE 77 19440, OCE 82-08394 and OCE 88-11005) to James MCCleave. 


\section{LITERATURE CITED}

Amos AF, Gordon AL, Schneider ED (1971) Water masses and circulation patterns in the region of the Blake-Bahama Outer Ridge. Deep Sea Res 18:145-165

Blache J (1977) Leptocephales des poissons Aguilliformes dans la zone sud du Golfe de Guinée. Faune Tropicale 10: $1-381$

Boëtius J, Harding EF (1985) A re-examination of Johannes Schmidt's Atlantic eel investigatıons. Dana 4:129-162

Böhlke EB (ed) (1989) Fishes of the western North Atlantic Mem Sears Fdn mar Res 1(9)

Böhlke EB, A1cCosker JE, Böhlke JE (1989) Family Muraenidae. In: Böhlke EB (ed) Fishes of the western North Atlantic. Mem Sears Fdn mar Res 1(9):723-763

Böhlke JE, Chaplin CCG (1968) Fishes of the Bahamas and adjacent tropical waters. Livingston Publishing, Wynnewood

Böhm E (1988) Subtropical fronts in the Sargasso Sea: a fouryear satellite analysis. MSc thesis, University of Rhode Island, Kingston

Böning C, Döscher WF, Budich G (1991) Seasonal transport variation in the western subtropical North Atlantic: experiments with an eddy-resolving model. J phys Oceanogr 21:1271-1289

Castle PHJ (1979) Early life-history of the eel Moringua edwardsi (Pisces, Moringuidae) in the western North Atlantic. Bull mar Sci 29:1-18

Castle PHJ (1984) Notacanthiformes and Anguilliformes development. In: Moser HG, Richards WJ (eds) Ontogeny and systematics of fishes. American Society of Ichthyologists and Herpetologists, Special Publication No 1 Allen Press, Lawrence, KS, p 62-93

Castle PHJ, Robertson DA (1974) Early life history of the congrid eels Gnathophis habenatus and G. incognitus in New Zealand waters. NZ J mar Freshwat Res 8(1):95-110

Castonguay M (1987) Growth of American and European eel leptocephali as revealed by otolith microstructure. Can J Zool 4:875-878

Castonguay M, MCCleave JD (1987) Vertical distribution, diel and ontogenetic vertical migration and net avoidance of leptocephali of Anguilla and other common species in the Sargasso Sea. J Plankton Res 9:195-214

Cohen DM, Dean D (1970) Sexual maturity and migratory behaviour of the tropical eel, Ahlia egmontis. Nature 227 . $189-190$

Cornillon P, Evans D, Large W (1986) Warm outbreaks of the Gulf Stream into the Sargasso Sea. J geophys Res 91 . $6583-6596$

Costin JM (1968) Direct current measurements in the Antilles Current. J geophys Res 73:3341-3344

Eriksen CC, Weller RA, Rudnick DL, Pollard RT, Regier LA (1991) Ocean frontal variability in the Frontal Air-Sea Interaction Experiment. J geophys Res 96:8569-8591

Ferraris CJ (1985) Redescription and spawning behavior of the muraenid eel Gymnothorax herrei. Copeia 1985: $518-520$

Fiadeiro ME, Veronis G (1983) Circulation and heat flux in the Bermuda Triangle. J phys Oceanogr 13:1158-1169

Field JG, Clarke KR, Warwick RM (1982) A practical strategy for analysing multispecies distribution patterns. Mar Ecol Prog Ser 8:37-52

Fishelson L (1992) Comparative gonad morphology and sexuality of the Muraenidae (Pisces, Teleostei). Copeia 1992:197-209

Gunn JT, Watts DR (1982) On the currents and water masses north of the Antilles/Bahamas arc. J mar Res 40:1-18
Halliwell GR Jr, Cornillon P (1989) Large-scale SST anomalies associated with subtropical fronts in the western North Atlantic during FASINEX. J mar Res 47:757-775

Halliwell GR Jr, Cornıllon P, Brink KH, Pollard RT, Evans DL, Regier LA, Toole JM. Schmitt RW (1991) Descriptive oceanography during the Frontal Air-Sea Interaction Experıment: medium- to large-scale variability. J geophys Res 96:8553-8567

Hulet WH, Robins CR (1989) The evolutionary significance of the leptocephalus larva. In: Böhlke EB (ed) Fishes of the western North Atlantic. Mem Sears Fdn mar Res 1(9) $657-1055$

Ingham MC (1975) Velocity and transport of the Antilles current northeast of the Bahama Islands. Fish Bull US 73 $626-632$

Kajihara T, Tsukamoto K, Otake T, Mochioka N, Hasumoto $\mathrm{H}$, Oyá M, Tabeta O (1988) Sampling leptocephali with reference to the diel vertical migration and the gears. Nippon Suisan Gakk 54:941-946

Kimura S, Tsukamoto K, Sugimoto T (1994) A model for the larval migration of the Japanese eel: roles of the trade winds and salinity front. Mar Biol 119:185-190

Kleckner RC, McCleave JD (1985) Spatial and temporal distribution of American eel larvae in relation to North Atlantic Ocean current systems. Dana 4:67-92

Kleckner RC, McCleave JD (1988) The northern limit of spawning by Atlantic eels (Anguilla spp.) in the Sargasso Sea in relation to thermal fronts and surface water masses. $\mathrm{J}$ mar Res 46:647-667

Kleckner RC, McCleave JD, Wippelhauser GS (1983) Spawning of American eel, Anguilla rostrata, relative to thermal fronts in the Sargasso Sea. Environ Biol Fish 9 289-293

Lai DY, Richardson PL (1977) Distribution and movement of Gulf Stream rings. J phys Oceanagr 7:670-683

Leaman KD, Molinari RL (1987) Topographic modification of the Florida Current by Little Bahama and Great Bahama Banks. J phys Oceanogr 17:1724-1736

Leaman KD Molinari RL, Vertes PS (1987) Structure and variability of the Florida current at $27^{\circ} \mathrm{N}$ : April 1982 July 1984. J phys Oceanogr 17:565-583

Lee TN, Johns W, Schott F, Zantopp R (1990) Western boundary current structure and variability east of Abaco, Bahamas at $265^{\circ} \mathrm{N}$. J phys Oceanogr 20:446-466

Leiby MM (1989) Family Ophichthidae: leptocephali. In: BöhIke EB (ed) Fishes of the western North Atlantic. Mem Sears Fdn mar Res 1(9):764-89?

McCleave JD (1993) Physical and behavioural controls on the oceanic distribution and migration of leptocephali. J Fish Biol 43 (Suppl A):243-273

McCleave JD, Kleckner RC (1987) Distribution of leptocephali of the catadromous Anguilla species in the western Sargasso Sea in relation to water circulation and migration. Bull mar Sci 41:789-806

McCleave JD, Miller MJ (1994) Spawning of Conger oceanicus and Conger triporiceps (Congridae) in the Sargasso Sea and subsequent distribution of leptocephati. Environ Biol Fish 39:339-355

McElroy DM, Moran P, Bermingham E, Kornfield I (1992) REAP: an integrated environment for the manipulation and phylogenetic analysis of restriction data. $J$ Hered 43 $157-158$

McWilliams JC (1983) On the mean dynamical balances of the Gulf Stream Recirculation Zone. J mar Res 41:427-460

Mied RP, Shen CY, Trump CL, Lindemann GJ (1986) Internalinertial waves in a Sargasso Sea front. $J$ phys Oceanogr $16: 1751-1762$ 
Miller MJ (1993) Species assemblages of leptocephali in the Sargasso Sea and Florida Current. PhD dissertation, University of Maine, Orono

Miller MJ, McCleave JD (1994) Species assemblages of leptocephali in the subtropical convergence zone of the Sargasso Sea. J mar Res 52:743-772

Moyer JT, Zaiser MJ (1982) Reproductive behavior of moray eels at Miyade-jima, Japan. Japan J Ichthyol 28:466-468

Niiler PP, Richardson WS (1973) Seasonal variabulity of the Florida Current. J mar Res 31:144-167

Olson DB, Backus RH (1985) The concentrating of organisms at fronts: a cold-water fish and a warm-core Gulf Stream ring. J mar Res 43:113-135

Olson DB, Schott FA, Zantopp R.J, Leaman KD (1984) The mean circulation east of the Bahamas as determined from a recent measurement program and historical XBT data. J phys Oceanogr 14:1470-1487

Pollard RT, Regier LA (1992) Vorticity and vertical circulation at an ocean front. J phys Oceanogr 22:609-625

Pratt LJ, Earles J, Cornillon P, Cayula JF (1991) The nonlinear behavior of varicose disturbances in a simple model of the Gulf Stream. Deep Sea Res 38:591-622

Richardson WS, Finlen JR (1967) The transport of Northwest Providence Channel. Deep Sea Res 14:361-367

Roff DA, Bentzen P (1989) The statistical analysis of DNA polymorphisms: $\chi^{2}$ and the problem of small samples. Mol Biol Evol 6:539-545

Rosenfeld LK, Molinari RL, Leaman KD (1989) Observed and modeled annual cycle of transport in the Straits of Flonda and east of Abaco Island, the Bahamas $\left(265^{\circ} \mathrm{N}\right)$. J geophys Res 94:4867-4878

Schmidt J (1922) The breeding places of the eel. Phil Trans R Soc Lond 211:179-208

Schmidt J (1931) Eels and conger eels of the North Atlantic Nature 128:602-604

Schmitz WJ Jr, Luyten JR, Schmitt RW (1993) On the Florida Current T/S envelope. Bull mar Sci 53:1048-1065

Schoth M, Tesch FW (1982) Spatial distribution of 0-group eel larvae (Anguilla sp) in the Sargasso Sea. Helgoländer wiss Meeresunters 35:309-320

Schoth M. Tesch FW (1984) The vertical distribution of 0-group Anguilla larvae in the Sargasso Sea with reference to other anguilliform leptocephali. Meeresforsch 30:188-195

Schott FA, Lee TN, Zantopp R (1988) Variability of structure and transport of the Florida Current in the period range of days to seasonal. J phys Oceanogr 18:1209-1230

Sinclair M (1988) Marine populations: an essay on population regulation and speciation. Washington Sea Grant Program, Seattle

This article was submitted to the editor
Smith DG (1979) Guide to the leptocephali Elopiformes, Anguilliformes, and Notacanthiformes. NOAA-Nat mar Fish Serv Circular No 424

Smith DG (1989a) Introduction to leptocephali. In: Böhlke EB (ed) Fishes of the western North Atlantic. Mem Sears Fdn mar Res 1(9):657-668

Smith DG (1989b) Family Congridae: leptocephali. In: Böhlke EB (ed) Fishes of the western North Atlantic. Mem Sears Fdn mar Res 1(9):723-763

Smith DG (1989c) Family Congridae. In: Böhlke EB (ed) Fishes of the western North Atlantic. Mem Sears Fdn mar Res 1(9):460-567

Stommel H, Niiler P, Anati D (1978) Dynamic topography and recirculation of the North Atlantic. J mar Res 36:449-468

Tesch FW (1982) The Sargasso Sea eel expedition 1979. Helgoländer wiss Meeresunters 35:263-277

Tesch FW, Wegner G (1990) The distribution of small larvae of Anguilla sp. related to hydrographic conditions 1981 between Bermuda and Puerto Rico. Int Rev ges Hydrobiol $75: 845-858$

Thresher RE (1984) Reproduction in reef fishes. TFH Publications, Neptune City, NJ

Tsukamoto K (1992) Discovery of the spawning area for Japanese eel. Nature 356:789-791

Vukovich FM, Crissman BW (1978) Observations of the intrusion of a narrow warm tongue into the Sargasso Sea using satellite and in situ data. J geophys Res 83:1929-1934

Wegner $G$ (1982) Main hydrographic features of the Sargasso Sea. Helgoländer wiss Meeresunters 35:385-400

Weller RA (1991) Overview of the frontal air-sea interaction experiment (FASINEX): a study of air-sea interaction in a region of strong oceanic gradients. J geophys Res 96 : $8501-8516$

Weller RA, Rudnick DL, Eriksen CC, Polzin KL, Oakey NS, Toole JW, Schmitt RW, Pollard RT (1991) Forced ocean response during the Frontal Air-Sea Interaction Experiment. J geophys Res 96:8611-8638

Wennekens MP (1959) Water mass properties of the Straits of Florida and related waters. Bull mar Sci Gulf Caribb 9: $1-52$

Wiebe $\mathrm{PH}_{1}$ Morton AW, Bradley AM, Backus RH, Craddock JE, Barber V, Cowles TJ, Flierl GR (1985) New developments in the MOCNESS, an apparatus for sampling zooplankton and micronekton. Mar Biol 87:313-323

Wippelhauser GS, McCleave JD, Kleckner RC (1985) Anguilla rostrata leptocephali in the Sargasso Sea during February and March 1981. Dana 4:93-98

Worthington LV (1976) On the North Atlantic circulation. The Johns Hopkins Oceanographic Studies No 6

Manuscript first received: March 30, 1994

Revised version accepted: January 4, 1995 